Download

https://doi.org/10.17721/2308-135X.2019.51.3-10

UDC $069(477+100)$

Beydik Olexander Oleksiovych, Doctor of Geographical Sciences, Professor

Taras Shevchenko National University of Kyiv, Kyiv, Ukraine, e-mail: aabeydik@gmail.com "> aabeydik@gmail.com

Topalova Olesya Illiyivna, candidate of geographical sciences

Melitopol Bogdan Khmelnytsky State Pedagogical University, Melitopol, Ukraine, e-mail: I.topal ova@yandex.ua ">

l.topalova@yandex.ua

Siruk Vady'm Yurijovych Taras Shevchenko National University of Kyiv, Kyiv, Ukraine, e-mail: vadimsiruk@gmail.com 


\section{TRADITIONAL AND NON-TRADITIONAL CULTURAL AND INFORMATION SYSTEMS OF UKRAINE AND THE WORLD}

The aim of the study is to elucidate the number and structure of the museum network in a global and national dimension; define the concepts of «museum», "cultural and informational system» and the main directions of improving museum business in Ukraine; analyze the basic structural and logical models and dynamics of museum development in Ukraine; better understand the idea of unusual museum projects in Ukraine and highlight the most original among them by subject, history of creation and value of exhibitions.

The methods and methodology of research. Expeditionary (a direct training with the expositions of non-traditional museum projects and field data collecting), monographic (an analysis of publications of leading museum scientists), comparative-geographical, cartographic, statistical (an analysis of number of museum institutions and their popularity in Ukraine), sociological (an identification of priorities of student youth in relation to non-traditional museum projects) computer technologies, modeling (a use of structural and logical models in the publication) methods were used in the disclosure of the topic.

The novelty of the research. The dynamics and trends of museum development in Ukraine and in the world, the structure of the array of publications on museum issues are elucidated, the priorities of student youth in relation to extraordinary museums and the top-7 most famous non-traditional museum projects of Ukraine (in order of discussion) are identified.

The results. It is proved that the share of non-traditional museums, museum projects and exhibitions in the «museum area» both in Ukraine and abroad is increasing, while at the same time in the Ukrainian national space it has been observed the actual disappearance of, until recently, unique expositions from such museum halls as the Museum of the History of Kyiv, the Museum of Taras Shevchenko on Chernychiy (Tarasova) mountain in Kaniv (Cherkasy region); by interviewing student youth, the most attractive and unpopular unconventional museums (world dimension) and the top 7 unusual museum projects of Ukraine (in order of discussion) were identified. The quantitative characteristics of the museum network and the popularity of museum institutions of Ukraine for the years 2000 -2017 are given.

The practical significance lies in the possibility of $\mathrm{i}$ implementation the results of the study into 
the educational process of higher education institutions in Ukraine (when teaching courses of excursion and museum studies, museum tourism, geography of tourism, basics of excursion) at the geographical, historical faculties of institutions of higher education in Ukraine) and the use of materials in the activities of museum and sightseeing institutions of Ukraine, in increasing public attention to traditional and non-traditional museum projects and expanding the idea of diversification of museum institutions.

Keywords: cultural and informational system, museum studies, museums, non-traditional museum projects, typology and classification of museums, dynamics of the museum network and demand for museum services.

\section{References}

1.Babaritska V. K., Korotkova A. Ya., Malinovskaya O. Yu. Excursion and museum studies: manual. K.

2.Beydik O. O, Mazurenko O. V, Trofimova S. Yu. Museums as reference, diversified and multidimensional links of the resource-recreational chain. - Ukraine's tourism resources. K. : Federation of Trade Unions of Ukraine, 1996. P.

50

56.

3. Beydik OO Museum History: National and European Dimension. - Scientific notes. Issue X. Rivne, 2012. - P. 40-44.

4. Bondar M. M, Mezentseva G. G, Slavin L. M. Essays on Museum Affairs. - K.: Naukova dumka, 1959.

5. Ionina N. O. 100 Great Museums of the World. - M .: Veche, 1999. -512 p. 
6. Konstantinova K. An unusual story // Mirror of the Week. 2007, №44(673).

7.Pop O. City hall dismisses the director of the Kiev Museum // Newspaper in Ukrainian. 2007. №

195

(478).

8. Smal IV Territorial structure of the recreational system of Chernihiv region of Ukraine // Kyiv Pedagogical Institute. MP Drahomanov. - K., 1993. - 278 p.

9.Smal I. V. Tourism Geography and Recreation: Handbook. - Ternopil. Bogdan Educational Book, 2010. - 208 p.

10. https://icom.museum/en/activities/standards-guidelines/museum-definition/

11. http://mincult.kmu.gov.ua/control/publish/article?art_id=245062916

12. https://simple.wikipedia.org/wiki/List_of_most_visited_art_museums_in the world

13. https://ukrstat.org/uk/operativ/operativ2012/cltr_rik/cltr_u/cltr_u.html

14. http://www.abs.gov.au/ausstats/abs @.nsf/featurearticlesbytitle/0CD49BFD994827D9CA25 74520010A476?OpenDocument

15. Kultura // Derzhavna sluzhba statystyky Ukrainy [Elektronnyi resurs]. - Rezhym dostupuy : https://ukrstat.org/uk/operativ/operativ2012/cltr rik/cltr u/cltr u.html. 
16. Merezha ta diialnist muzeiv u 2016 rotsi : ekspres-vypusk № 149/0/05.4vn-17 vid 11.04.2017 // Derzhavna sluzhba statystyky Ukrainy [Elektronnyi resurs]. - Rezhym dostupu y: http://w ww.ukrstat.gov.ua/express/expr2017/expres_u.html.

17.Rutynskyi M. Y., Stetsiuk O. V. Muzeieznavstvo : navch. posib. -: Znannia, 2008. - 428 p.

18. YUreneva T. YU.: ucheb. - M. : Akademicheskij Proekt, 2006.

Received Editorial Board 08.11.19 